\title{
PEMANFAATAN KOTORAN AYAM UNTUK PENINGKATAN KUALITAS PUCUK TEBU SEBAGAI PAKAN RUMINANSIA
}

\author{
C. I. Sutrisno, B.W.H.E Prasetyono, dan E. Ali \\ Laboratorium Teknologi Makanan Ternak \\ Fakultas Peternakan Universitas Diponegoro Semarang
}

\section{ABSTRACT}

Experiment was carried out in two stages. The first was aimed to study the viability of microbe of dried-oven manure and dried-sunshine manure. Completely Randomized Design (CRD), 3 treatments and 4 replications, was used throughout the experiment with content of manure microbe as the parameters. The research result indicates that the way of draining degraded the viability of microbia manure. Manure microbia's viability of dried-oven manure was better than that of the dried-sunshine manure.

The second was aimed to investigate the effect of dried-manure as starter with different time of fermentation on the quality of fermented sugar cane. Completely Randomized Design, factorial pattern $3 \times 3$ by 3 replications was employed during the experiment. The first factor was starter levels (A) : 0,15 and $30 \%$, while the second was different time of fermentation (W): $), 4$, and 8 week. Parameter perceived by fermented fiber component, which analysis by Analysis of Variance, while the differences among the treatment were tested with the Duncan Multiple Range Test (DMRT), continued by Polinomial Ortogonal. Fermented sugar cane by dry manure with different time of fermentation degraded the rate of NDF and ADF. The best performance was reached at $30 \%$ of starter and 4 weeks of fermentation

Key words: Viability, Bacteria, Draining, Manure, $N D F, A D F$

\section{PENDAHULUAN}

Pandangan masa lalu, pertanian merupakan upaya sistematis peningkatan produksi dalam subsistem usaha tani budidaya pertanian (on-farm agribusiness). Perkembangan selanjutnya, muncul berbagai tantangan, baik internal maupun eksternal secara nasional maupun internasional, sehingga pandangan diatas perlu digeser dan diubah.

Pengembangan pertanian kedepan harus merupakan upaya pengembangan yang utuh dan menyeluruh pada semua subsistem pertanian, dengan merigembangkan dan memanfaatkan berbagai teknologi terkait. Masing-masing sektor tidak hanya merupakan pendukung atau pelengkap tetapi sekaligus juga sebagai pemicu dan pemacu pembangunan pertanian secara terpadu yang tangguh (Saragih, 2000).

Penggunaan teknologi pertanian yang tidak sesuai dengan kebutuhan, tidak ramah lingkungan dan belum memenuhi kelayakan taknis suatu teknologi, cenderung akan menyebabkan pendayagunaan sumberdaya lahan diambang batas kemampuan. Lahan dimanfaatkan secara intensif untuk memenuhi kebutuhan hidup dan secara sadar maupun tidak untuk memproduksi karbohidrat. Hara yang ada menjadi terkuras sehingga terjadi penurunan produktivitas dan efisiensi lahan (Karama dan Abdurachman, 1994). Efisiensi dan produktivitas dapat ditingkatkan melalui penerapan teknologi inovatif, optimalisasi sumberdaya lahan dan tenaga kerja serta membangun kelembagaan usaha bersama yang berorientasi pada agribisnis yang berkelanjutan (Wen, 1998). Teknologi pengolahan limbah merupakan salah satu alternatif dalam penyediaan pakan, dan bermanfaat pula dalam mengurangi pencemaran lingkungan (Sutrisno, 1999).

Pengembangan ternak ruminansia dapat dikaji melalui dua pendekatan, yakni produksi dan produktivitas ternak. Penyediaan pakan hijauan secara kontinyu sangat dibutuhkan untuk pengembangan ternak ruminansia. Pertanian yang makin berkembang mendorong tumbuh kembang bahan pakan yang berasal dari limbah pertanian. Pemanfaatan limbah pertanian menjadi pakan bernilai cukup tinggi merupakan salah satu alternatip dalam penyediaan pakan dan bermanfaat pula dalam mengurangi pencemaran lingkungan. Salah satu upaya agar penampilan produksi ternak meningkat adalah dengan menyediakan pakan berkualitas dengan memanfaatkan kotoran ayam yang merupakan limbah peternakan ayam.

Kotoran ayam merupakan hasil buangan metabolisme yang terdiri dari feses dan urine 
(Sahidu, 1983), mengandung $45 \%$ nitrogen total sebanyak 40-60\% dalam bentuk non protein nitrogen (NPN). Menurut Rasyaf (1999), produk limbah peternakan ayam dibedakan menjadi dua bentuk. Bentuk pertama berupa kotoran ayam yang, bercampur dengan bahan litter, bentuk ini mengandung banyak serat kasar sehingga biasanya digunakan untuk pupuk. Bentuk kedua adalah kotoran ayam murni, yang dihasilkan oleh peternakan dengan sistem cages, kandungan serat kasarnya relatif rendah sehingga memungkinkan digunakan sebagai sumber pakan. Potensi pemanfaatan kotoran ayam sebagai starter dalam pembuatan silase sangat besar (Laconi, 1992).

Peningkatan mutu pakan dengan menggunakan kotoran ayam dapat dilakukan dengan metode Wastelag yaitu proses pembuatan silase dengan memfermentasikan limbah pertanian atau by product yang ditambah limbah ternak (Laconi, 1992). Penggunaan kotoran ayam segar sebagai starter dalam fermentasi menjadi kendala bagi peternak yang tidak mempunyai peternakan unggas. Kotoran ayam kering masih baik digunakan sebagai starter apabila jumlah mikrobia yang dikandung tidak berbeda jauh dengan kotoran ayam segar.

Pengeringan merupakan suatu metode untuk mengeluarkan atau menghilangkan sebagian air dari bahan dengan cara menguapkan air tersebut dengan menggunakan energi panas (Winarno et al., 1980). Melalui pengeringan, volume bahan menjadi kecil, berat bahan berkurang, sehingga memudahkan dalam pengangkutan dan pengemasan serta menghemat ruang saat penyimpanan (Widayati dan Widalestari, 1996).

Limbah pertanian umumnya mempunyai nilai nutrisi yang rendah dikarenakan proteinnya rendah dan ligninnya tinggi (Mochtar dan Tedjowahyono, 1980). Peningkatan kualitas limbah pertanian dapat dilakukan melalui pengolahan, salah satunya dengan fermentasi.

Pucuk tebu potensial untuk pakan karena tanaman tebu dipanen pada musim kemarau pada saat produksi rumpu: rendah kualitas dan kuantitasnya, dengan produksi sekitar 4 ton/ha (BPS, 2003). Pucuk tebu dapat digunakan untuk pakan ternak, penggunaannya dapat dalam bentuk segar atau dalam bentuk awetan seperti silase, wafer maupun pellet. Pucuk tebu dapat digunakan sebagai pengganti rumput Gajah sebagai pakan hijauan tanpa ada pengaruh negatifnya terhadap ternak ruminansia, baik sapi potong maupun perah (Mochtar dan Tedjowahyono, 1980).

\section{METODOLOGI}

Penelitian ini dilakukan dalam dua tahap. Penelitian tahap-1 dilakukan untuk menggali informasi pengaruh alat pengering terhadap berbagai mikrobia yang terdapat dalam manure ayam. Penelitian diawali dengan membagi kotoran ayam segar menjadi 5 kelompok yaitu ayam segar, kotoran ayam disimpan 2, 4, 6 dan 8 hari pada suhu kamar. Masing-masing kelompok dihitung total mikrobia. Jumlah mikrobia paling tinggi dibagi 3 kelompok yaitu kotoran ayam segar dan diperlakukan menurut petunjuk Sutrisno et al, (2005).

Penelitian menggunakan Rancangan Acak Lengkap (RAL) dengan 3 perlakuan dan 4 ulangan. Perlakuan yang dipakai adalah: PI (Kotoran ayam segar), P2 (Kotoran ayam dikeringkan dengan oven) dan P3 (Kotoran ayam dikeringkan dengan sinar matahari). Data yang diperoleh dianalisis ragam, sedangkan perbedaan antar perlakuan diuji dengan Uji Wilayah Ganda Duncan (Steel dan Torrie, 1993).

Parameter yang diamati jumlah total bakteri, fungi, bakteri amilolitik, proteolitik, lipolitik dan pembentuk asam dengan menggunakan metode cawan tuang (Fardiaz, 1989)..

Penelitian tahap-2 bertujuan untuk mengkaji pengaruh penggunaan kotoran ayam kering dicampur tetes sebagai starter untuk fermentasi pucuk tebu dengan lama pemeraman yang berbeda, terhadap kualitas hasil fermentasi pucuk tebu.

Penelitian menggunakan Rancangan Acak Lengkap bderpola faktorial $3 \times 3$ dengan 3 ulangan, Faktor pertama adalah aras starter (A) sebanyak 0, 15 dan 30\%, sedangkan Faktor kedua adalah lama pemeraman (W) selama 0,4 , dan 8 minggu. Parameter yang diamati adalah komponen serat terutama Neutral detergent Fiber (NDF) dan Acid Detergent Fiber (ADF) dengan metode Goering dan van Soest (1970). Data yang diperoleh dianalisis ragam, sedangkan perbedaan antar perlakuan diuji dengan Uji Wilayah Ganda Duncan, dilanjutkan dengan Polinomial Ortogonal (Steel dan Torrie, 1993).

\section{HASIL DAN PEMBAHASAN}

Pengaruh Pengeringan terhadap Daya Hidup Mikrobia

Hasil analisis ragam menunjukkan terdapat pengaruh nyata $(\mathrm{P}<0,05)$ cara pengeringan terhadap daya hidup total Bakteri, 
total Fungi, bakteri Amilolitik, bakteri Proteolitik, bakteri Llipolitik dan bakteri pembentuk asam seperti tersaji dalam Tabel 1 .

Tabel I memperlihatkan perbedaan yang nyata antara PI, P2 dan P3 terhadap daya hidup total bakteri dan total fungi dan cara pengeringan menyebabkan terjadinya penurunan jumlah- total bakteri dan total fungi. Perlakuan P1 mempunyai jumlah bakteri dan fungi tertinggi diikuti P2 dan P3, hal ini dikarenakan pada Pl belum dilakukan pengeringan sehingga masih mempunyai kadar air cukup tinggi (69\%), sedangkan pada perlakuan P2 dan P3 telah dilakukan pengeringan yang menyebabkan terjadi pengurangan kadar air sehingga kelembaban berkurang yang menyeba'skan pertumbuhan bakteri dan fungi terhambat. Bakteri memerlukan kelembaban yang tinggi untuk pertumbuhannya. Kelembaban yang tinggi dapat dicapai apabila substrat mempunyai kadar air tinggi (Suriawira, 1996). Perlunya air untuk pertumbuhan dan perkembangan bakteri karena air merupakan komponen utama penyusun plasma sel bakteri
(Lidya dan Djenar, 2000). Air juga berperan sebagai pelarut nutrisi dalam sel sehingga kalau ketersediaannya menurun dapat menyebabkan gangguan metabolisme bakteri. Jumlah Total bakteri dan fungi pada pelakuan P2 lebih tinggi dari pada P3. Hal tersebut disebabkan karena cara pengeringan dengan oven pada $\mathrm{P} 2$ lebih stabil dan menghindarkan kotoran ayam kontak langsung dengan sinar matahari. Perlakuan P3 menunjukkan bahwa jumlah total bakteri dan fungi paling rendah, hal tersebut disebabkan radiasi sinar matahari langsung diterima kotoran ayam dapat menyebabkan kematian pada bakteri dan fungi. Hal tersebut sesuai dengan pendapat Lidya dan Djenar (2000) yang menyatakan bahwa kebanyakan bakteri mati oleh cahaya langsung dari matahari dan sinar-sinar violet, ultra violet dan sinar biru sangat kuat daya mematikan fungi. Nutrisi kotoran ayam cukup baik karena mengandung unsur $\mathrm{C}, \mathrm{H}$, $\mathrm{O}$ dan $\mathrm{N}$ cukup tinggi yang sangat diperlukan oleh bakteri dan fungi untuk menyusun protoplasma (Dwidjoseputro, 1998).

Tabel 1. Jumlah Mikrobia pada Berbagai Cara Pengeringan

\begin{tabular}{ccccccc}
\hline Perlakuan & Total Bakteri & $\begin{array}{c}\text { Total } \\
\text { Fungi }\end{array}$ & $\begin{array}{c}\text { Bakteri } \\
\text { Amilolitik }\end{array}$ & $\begin{array}{c}\text { Bakteri } \\
\text { Proteolitik }\end{array}$ & $\begin{array}{c}\text { Bakteri } \\
\text { Lipolitik }\end{array}$ & $\begin{array}{c}\text { B. Pembentuk } \\
\text { Asam }\end{array}$ \\
\hline P1 & $9,6 \times 10^{11 \mathrm{a}}$ & $1,6 \times 10^{5 \mathrm{a}}$ & $3,7 \times 10^{4 \mathrm{a}}$ & $3,6 \times 10^{4 \mathrm{a}}$ & $1,1 \times 10^{3 \mathrm{a}}$ & $41,75 \times 10^{1 \mathrm{a}}$ \\
P2 & $7,0 \times 10^{10 \mathrm{~b}}$ & $9,9 \times 10^{3 \mathrm{~b}}$ & $3,5 \times 10^{3 \mathrm{~b}}$ & $5,5 \times 10^{3 \mathrm{~b}}$ & $4,4 \times 10^{2 \mathrm{~b}}$ & $38,25 \times 10^{1 \mathrm{~b}}$ \\
P3 & $1,7 \times 10^{10 \mathrm{c}}$ & $2,6 \times 10^{3 \mathrm{c}}$ & $6,0 \times 10^{2 \mathrm{c}}$ & $4,0 \times 10^{2 \mathrm{c}}$ & $3,6 \times 10^{2 \mathrm{~b}}$ & $34,75 \times 10^{1 \mathrm{c}}$ \\
\hline
\end{tabular}

Superskrip berbeda pada kolom yang sama menunjukkan perbedaan yang nyata $(P<0,05)$

Perbedaan yang nyata antara P1, P2 dan P3 terhadap daya hidup bakteri amilolitik dan bakteri proteolitik, dengan cara pengeringan menyebabkan terjadinya penurunan jumlah bakteri amilolitik dan bakteri proteolitik. Perlakuan Pl mempunyai jumlah bakteri amilolitik dan proteolitik tertinggi diikuti P2 dan P3. Perlakuan P1 mempunyai kadar air yang lebih tinggi dari pada P2 dan P3 yang telah mengalami pengeringan, sedangkan bakteri amilolitik dan proteolitik membutıhkan air dalam proses kehidupannya (Suriawiria, 1996).

Terdapat perbedaan nyata antara perlakuan P2 dengan P3, dan jumlah bakteri amilolitik maupun lipolitik perlakuan P2 lebih tinggi daripada P3 karena pengeringan P2 tidak terkena sinar matahari langsung yang mematikan bakteri dan radiasi sinar matahari akan merusak sel mikrobia (Suriawiria, 1996). Sinar matahari yang bersifat germisida antara lain sinar ultra violet, sinar infra merah, sinar $\alpha$, $\beta$ dan $\gamma$ (Wanto dan Soebagyo, 1980).

Terdapat perbedaan yang nyata antara P1, P2 dan P3 terhadap daya hidup bakteri pembentuk asam, dan cara pengeringan menyebabkan terjadinya penurunan jumlah bakteri lipolitik maupun pembentuk asam. Pl mempunyai jumlah bakteri lipolitik dan pembentuk asam tertinggi diikuti P2 dan P3.

Jumlah bakteri lipolitik pada P1 berbeda nyata dengan P2 dan P3 hal tersebut disebabkan karena hasil analisis proksimat kotoran ayam menunjukkan bahwa kandungan lemak kasar pada P1 lebih tinggi dibandingkan P2 dan P3 (5,40 vs 3,18 dan $3,23 \%$ ) menyebabkan jumlah bakteri lipolitik lebih tinggi dibandingkan pada P2 dan P3. Hal tersebut sesuai dengan pendapat Frazier dan Westhoff (1988) yang menyatakan bahwa keberadaan suatu jenis bakteri berbanding lurus dengan ketersediaan nutrisi dalam substrat. Bakteri lipolitik mempunyai kemampuan mengubah lemak 
menjadi sumber energi yang berguna bagi kehidupan bakteri. Perlakuan P2 dan P3 tidak berbeda nyata karena kandungan lemak kasarnya tidak jauh berbeda dan kemungkinan bakteri lipolitik lebih tahan terhadap sinar ultra violet dan fluktuasi suhu.

Jumlah bakteri pembentuk asam pada $\mathrm{Pl}$ berbeda nyata dengan P2 dan P3 hal tersebut disebabkan bakteri pembentuk asam tidak tahan terhadap pemanasan akibat proses pengeringan. Lidya dan Djenar (2000) menyatakan bahwa suhu tinggi dapat merusak pertumbuhan mikrobia termasuk bakteri pembentuk asam. Kandungan nutrisi dalam kotoran ayam mempunyai pengaruh dalam pertumbuhan bakteri pembentuk asam. Kandungan serat kasar Pl lebih tinggi dibanding P2 dan P3 (20,35 vs 11,84 dan 14,39\%). Selain itu kandungan BETN nya pun cukup tinggi $(53,60$ vs 60,01 dan 60,33 ). Adanya nutisi yang cukup dari serat kasar dan BETN mampu merangsang pertumbuhan bakteri pembentuk asam.

\section{Pengaruh Fermentasi Pucuk Tebu dengan Kotorsn Ayam Kering}

Pengaruh aras dan lama pemeraman terhadap kadar NDF disajikan dalam Tabel 2.

Analisis ragam menunjukkan tidak adanya interaksi antara penambahan aras starter dengan lama pemeraman terhadap kadar NDF hasil fermentasi pucuk tebu, tetapi aras dan lama pemeraman berpengaruh sangat nyata $(P<0,01)$ terhadap penurunan NDF. Hubungan antara aras starter dan kadar NDF menghasilkan persamaan linier $\mathrm{Y}=86,11-\mathrm{C}, 84 \mathrm{X}(\mathrm{r}=0,27)$. Aras starter $30 \%$ lebih baik $(\mathrm{P}<0,0 \mathrm{i})$ dibandingkan starter 0 maupun $15 \%$. Menurunnya kadar NDF menunjukkan bahwa selama fermentasi terjadi pemutusan ikatan lignoselulosa dan lignohemiselulosa yang dipenaruhi oleh $\mathrm{pH}$, mikrobia yang berkembang dan dipertahankannya kondisi anaerob. Pertumbuhan mikrobia pada aras starter $15 \%$ belum optimal, sehingga kurang mampu mencerna dan merombak serat. Lama pemeraman berpengaruh sangat nyata terhadap NDF, pemeraman selama 8 minggu terbaik dibandingkan 0 dan 4 minggu dengan membentuk persamaan linier $Y=91,78-2,73 X$ dengan $r=0,87$.

Muchtadi dan Laksmi (1980) menyatakan bahwa pertumbuhan mikrobia sangat dipengaruhi lingkungan fisik (suhu), kimia (kebutuhan pakan) dan biologi berupa pengaruh pertumbuhan mikrobia lainnya. Selain suhu, faktor fisik lainnya adalah air, kelembaban, pH, oksigen dan cahaya (Lidya dan Djenar (2000). Penurunan NDF juga dikarenakan terjadi degradasi selulosa oleh selulase yang dihasilkan tanaman, menurut Card dan Nesheim (1985) selain bakteri dan protosoa, didalam sekum ditemukan juga fungi dan bakteri yang berasal dari serat tanaman yang mampu mensekresi enzim selulolitik

Pengaruh aras starter dan lama pemeraman terhadap kadar ADF disajikan dalam Tabel 3.

Tabel 2.- Kadar NDF Hasil Fermentasi Pucuk Tebu dengan Kotoran Ayam

\begin{tabular}{ccccc}
\hline Aras Starter & \multicolumn{3}{c}{ Lama Pemeraman (minggu) } & Rata=-Rata \\
\cline { 2 - 4 }$(\boldsymbol{\%})$ & $\mathbf{0}$ & $\mathbf{4}$ & $\mathbf{8}$ & $(\%)$ \\
\hline 0 & 95,00 & 83,22 & 80,03 & $86,08^{\mathrm{A}}$ \\
15 & 90,86 & 83,32 & 76,83 & $83,67^{\mathrm{A}}$ \\
30 & 91,79 & 79,64 & 71.66 & $81,03^{\mathrm{B}}$ \\
Rata-Rata & $92,85^{\wedge}$ & $82,06^{\mathrm{B}}$ & $76,17^{\mathrm{B}}$ & 83,59 \\
\hline
\end{tabular}

Superskrip dengan huruf besar berbeda pada baris dan kolom yang sama menunjukkan perbedaan yang sangat nyata $(P<0,01)$

Tabel 3.- Kadar ADF Hasil Fermentasi Pucuk Tebu dengan Kotoran Ayam

\begin{tabular}{ccccc}
\hline $\begin{array}{c}\text { Aras Starter } \\
(\%)\end{array}$ & $\mathbf{3}$ & Lama Pemeraman (minggu) & Rata=-Rata \\
\cline { 2 - 4 } & $\mathbf{0}$ & $\mathbf{4}$ & $\mathbf{8}$ & $\mathbf{( \% )}$ \\
\hline 0 & 64,73 & 55,89 & 52,94 & $57,85^{\mathrm{A}}$ \\
15 & 63,70 & 54,65 & $46,69$. & $55,01^{\mathrm{A}}$ \\
30 & 60,70 & 51,74 & 43,48 & $51,97^{\mathrm{B}}$ \\
Rata-Rata & $63,04^{\mathrm{A}}$ & $54,09^{\mathrm{B}}$ & $47,70^{\mathrm{B}}$ & 54,95 \\
\hline
\end{tabular}

Superskrip dengan huruf besar berbeda pada kolom yang sama menuajukkan perbedaan yang sangat nyata $(P<0,01)$ 
Analisis ragam menunjukkan tidak adanya interaksi antara penambahan aras starter dengan lama pemeraman terhadap kadar ADF hasil fermentasi pucuk tebu, tetapi aras dan lama pemeraman berpengaruh sangat nyata $(\mathrm{P}<0,01)$. Kandungan ADF terbaik dicapai pada aras $30 \%$, disusul aras $15 \%$ dan yang tanpa starter, dengan membentuk persamaan linier $\mathrm{Y}=57,89-0,98 \mathrm{X}$ dengan $r=0,31$. Penurunan ADF menunjukkan bahwa fermentasi pucuk tebu dengan starter kotoran ayam kering menyebabkan depolimerisasi substrat sehingga mudah dicerna. Hal ini sesuai dengan pendapat van Soest (1987) yang menyatakan bahwa fermentasi sebagai perlakuan biologis dapat menyebabkan depolimerisasi selulosa menjadi selobiosa dan glukosa sehingga meningkatkan nilai kecernaan sekaligus utilitas pakan berserat yang difermentasi.

Kadar ADF menurun seiring dengan bertambahnya lama pemeraman membentuk persamaan linier $\mathrm{Y}=62,64-2,56 \mathrm{X}$ dengan nilai $\mathrm{r}$ $=0,82$. Penurunan $\mathrm{ADF}$ terjadi pada lama pemeraman 4 dan 8 minggu $(P<0,01)$, hal ini dikarenakan selama fermentasi terjadi perombakan hemiselulosa menjadi gula sederhana yang larut dalam pemanasan deterjen asam sehingga meningkatkan kandungan ADS dan menurunkan kandungan ADF. Hal ini sesuai dengan Anggorodi (1984) yang menyatakan bahwa hemiselulosa tidak larut dalam air mendidih tetapi larut dalam larutan alkali dan terhidrolisis dengan larutan asam encer.. Lama pemeraman 8 minggu memberikan waktu bagi mikrobia untuk berkembang biak. Menurut Zulbadri, et ul. (1991), adanya aktivitas mikrobia fermentasi akan merombak senyawa yang sulit dicerna menjadi glukosa dan fruktosa

\section{KESIMPULAN}

Hasil penelitian menunjukkan bahwa cara pengeringan menurunkan daya hidup mikrobia pada kotoran ayam. Daya hidup mikrobia kotoran ayam pada pengeringan dengan oven lebih baik daripada dengan pengeringan sinar matahari. Penggunaan kotoran ayam kering dan lama pemeraman yang berbeda pada fermentasi pucuk tebu dapat menurunkan kadar NDF dan ADF. Hasil terbaik dicapai pada penggunaan $30 \%$ starter dan lama pemeraman 4 minggu

\section{DAFTAR PUSTAKA}

Anggorodi, R. 1984. Ilmu Makanan Ternak Umum. Penerbit PT Gramedia. Jakarta

Biro Pusat Statisti. 2003. Kerangka Teori dan Analisis, Tabel input/output. BPS Jakarta

Card, L.E dan M.C. Nesheim. 1985. Poultry Production. Lea \& Febiger, Philadelpia.

Dwidjoseputro, D. 1998. Dasar-dasar Mikrobiologi. PT. Djambatan. Jakarta.

Fardiaz, S. 1989. Mikrobiologi Pangan. Pusat Antar Universitas Pangan dan Gizi, Institut Pertanian Bogor, Bogor.

Frazier, W.C. dan D. C. Westhoff. 1988. Food Microbiology. McGraw-Hill Book Company, New York.

Goering, H.K., dan van Soest. 1970. Forage fibre analysis (apparatus, reagents, procedures) Dept Agr Handbook No. 379. Government Printing Office, Washington DC

Karama, S dan A. Abdurachman. 1994. Optimasi pemanfaatan sumberdaya lahan berwawasan lingkungan, dalam Prosiding Simposium Tanaman Pangan III. Pusat Penelitian dan Pengembangan Tanaman Pangan, Bogor.

Laconi, E.B. 1992. Pemanfaatan Manure Ayam sebagai Suplemen Non Protein Nitrogen (NPN) dalam Pembuatan Silase Jerami Padi untuk Ternak Kerbau. Fakultas Peternakan, Institut Pertanian Bogor, Bogor. (Thesis).

Lidya B dan N.S. Djenar. 2000. Dasar Bioproses. Direktorat Pembinaan Penelitian dan Pengabdian pada Masyarakat, Direktorat Jendral Pendidikan Tinggi, Departemen Pendidikan Nasional, Jakarta

Muchtadi, D dan Laksmi. 1980. Petunjuk Praktek Mikrobiologi Hasil Pertanian. Penerbit Departemen Pendidikan dan Kebudayaan. Jakarta

Muchtar, M, dan Tedjowahjono. 1985. Pemanfaatan hasil samping industri gula dalam menunjang pengembangan 
peternakan, dalam Rangkuti, M., A. Musofie, P. Sitorus, I.P Kompiang, N. Kusumowardhani, dan A Roesjat (Eds). Prosiding Seminar Pemanfaatan Limbah Tebu untuk Pakan Ternak. Pusat Penelitian dan Pengembangan Peternakan. Grati, hal 59-65

Rasyaf, M. 1999. Beternak Ayam Pedaging. Penebar Swadaya, Jakarta.

Sahidu, S. 1983. Kotoran Ternak sebagai Sumber Energi. Dewaruci, Jakarta.

Saragih, B. 2000. Kebijakan Pengembangan Agribisnis di Indonesia Berbasiskan Bahan Baku Lokal. Buletin Peternakan UGM Edisi Tambahan 2000, Yogyakarta: $6-11$

Steel, R.G.D dan J.H. Torrie. 1993.. Prinsip dan Prosedur Statistika. Suatu Pendekatan Biometrika. PT Gramedia Pustaka Utama. Jakarta (Diterjemahkan oleh B. Sumantri).

Suriawira, U. 1996. Mikrobiologi Air dan Dasardasar Pengolahan Buangan secara Biologis. Alumni, Bandung.

Sutrisno, C.I. 1999. Pemanfaatan Limbah Pertanian dan Limbah Rumah Potong Hewan sebagai Pakan Sapi Potong. .Jurnal Lingkungan 3(II): $54-58$
Sutrisno, C..I. 2005. Potensi Pemanfaatan Manure Kering. Jurnal Ilmu Pengetahuan dan Teknologi 3(I): $50-58$

Van Soest, P.J. 1987. Nutrition Ecology of the Ruminant. Cornell University. Press. Oregon

Wanto, L.P. dan A. Soebagyo. 1980. Dasar-dasar Mikrobiologi Industri. Edisi I. Departemen Pendidikan dan Kebudayaan, Jakarta.

Wen, S.M. 1998. Development of the Cooperative Economy in Rural China. China's Rural Development Miracle. University of Queensland, St Lucia

Widayati, E dan Y. Widalestari. 1996. Limbah untuk Pakan Ternak. Cetakan I. PT. Trubus Agrisana, Surabaya.

Winarno, F.G., S. Fardiaz dan D. Fardiaz. 1980. Pengantar Teknologi Pangan. PT. Gramedia, Jakarta.

Zulbardi, M., M. Sitorus dan T. manurung. 1991. Karakteristik selase onggok segar dengan pengawet molases, dalam B. Srigandono, D. Rahmadi, M.I. Sri Wuwuh, Umiyati, A.M., Kusrahayu. Sumarsono, Supardi, B.I.M Tampoeioolon (Eds). Prosiding Seminar Nasional Usaha Peningkatan Produktivitas Peternakan dan Perikanan. Ilal $559-564$ 